\title{
The art of necessary compromise
}

I nternational relief groups may insist that they're above politics, but a controversial new book produced by one of the world's bestknown aid agencies, Médecins Sans Frontières (MSF), reveals that their ability to work in areas of conflict often hinges upon "grubby negotiations."

MSF's collection of essays and case studies, Humanitarian Negotiations Revealed: The MSF Experience, contends that effective humanitarian action has long been based on "power games" and difficult compromises, and for organizations to "believe, and far more importantly, to behave as if this were not the case is to court disaster" (www .msf-crash.org/livres/en/humanitarian -negotiations-revealed).

"Somehow there is this idea that there was a golden age of humanitarian action in which NGOs [nongovernmental organizations] were welcome, protected and respected. We know that such a golden age never existed," Claire Magone, coeditor of the book and director of studies at Fondation Médecins Sans Frontières, the Centre de Réflexion sur l'Action et les Savoirs Humanitaires, explained at a panel discussion at the University of Ottawa in Ontario on Feb. 15. "Humanitarian action has always been trying to find a shared interest with the powers that be. In other words, manipulation of aid is not a misuse of its vocation, but a condition of its existence."

Nevertheless, many humanitarian organizations still treat such moral ambiguity as taboo or, at best, a necessary evil, and consequently there's been little public discussion about the benchmarks against which to judge acceptable from unacceptable compromises.

For MSF, "everything is open to negotiation," including "the safety of personnel, the presence of expatriates, MSF's intervention priorities, the qual- ity of the assistance provided, [and] control over resources." However, "negotiation frameworks do not include universal markers indicating the line that must not be crossed; and MSF must therefore pay attention to the developing dynamic of each situation and to its own ability to revoke compromises that were only acceptable because they were temporary" (www .msf-crash.org/livres/en/humanitarian -negotiations-revealed).

Common concessions have included working in a government-prescribed intervention zone or keeping silent about oppressive policies in the interest of obtaining access to a population or preserving the possibility of future projects in the region, Magone said.

In 1992, for example, MSF-Holland relinquished a project to intervene in a region of Myanmar where the government was brutally repressing minority groups in exchange for authorization to

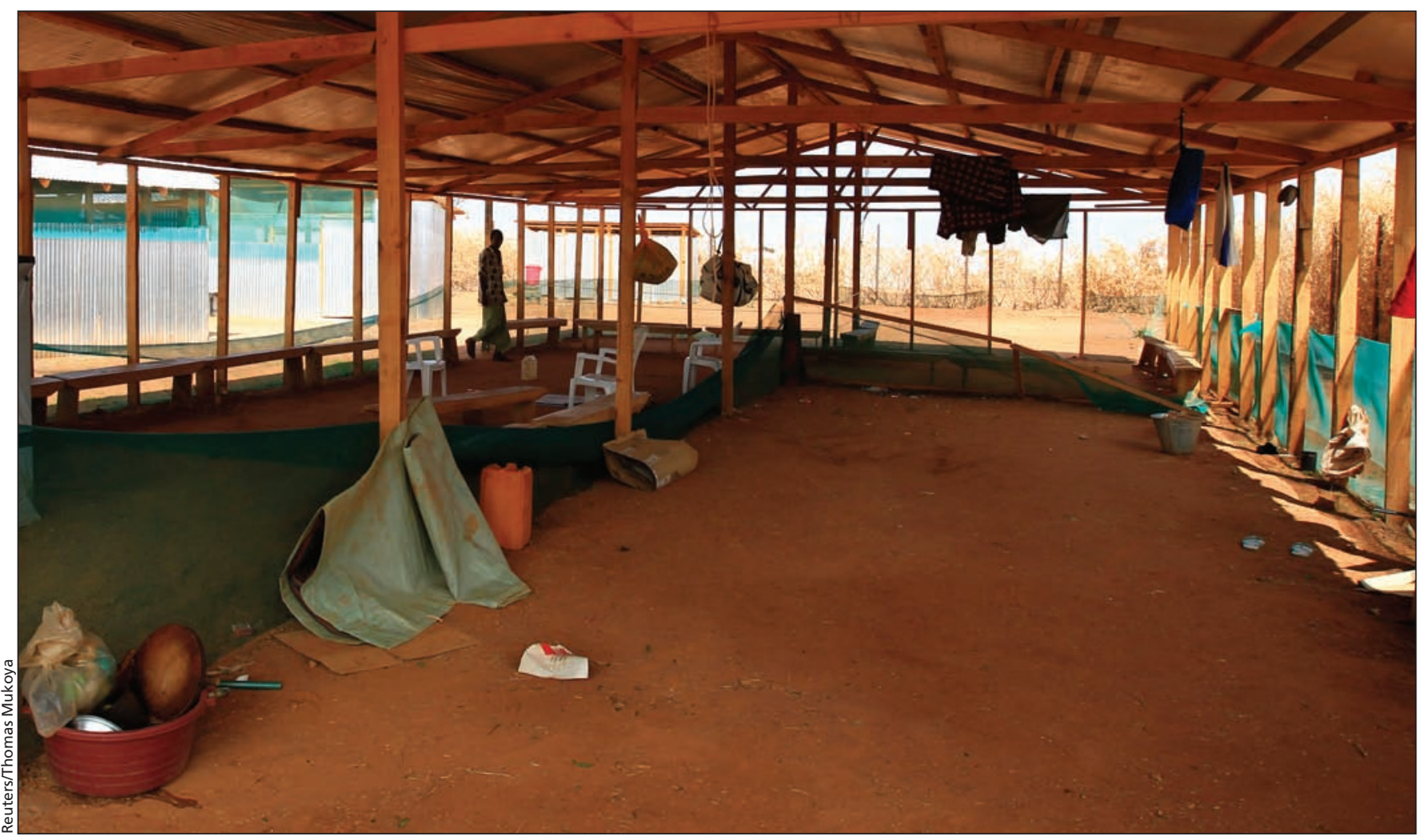

A deserted compound of a Médecins Sans Frontières clinic in Dadaab, Kenya. 
intervene elsewhere within the nation. The Swiss section of MSF made a similar concession in 1999 to enter the country. In both instances, the two MSF sections agreed not to publicly criticize the authorities.

Consequently, MSF was able to carry off a large-scale HIV treatment program that otherwise might not have been possible.

While agreeing to be muzzled may seem at odds with the humanitarian principle of reporting injustice, it's often impossible to "maintain access at the same time you're condemning publicly one of the parties that has control of the ground," Bogdan Dumitru, panelist and security director at CARE Canada, said. "Sometimes silent diplomacy functions a lot better than open advocacy."

There is a limit, though, Dumitru added. "When you get to the end of the available means to negotiate for the rights of the people you're trying to assist, then basically you take your gloves off and go public. It's not an easy decision because if you take sides in Somalia, for example, your opera- tions in Pakistan and Afghanistan will certainly be affected."

Magone admitted it can be tricky to navigate the "blurry but very real line beyond which assistance for victims turns into support for their tormentors."

Some clear indicators of when an organization may have crossed that line include losing control of resources on the ground for an extended period of time, or poor health outcomes within the population groups that were the target of a relief program, Magone explained.

For example, MSF recently pulled out of detention centres in Libya after it became clear they were treating the same patients over and over again. "We were treating them to be fit enough to get tortured again."

But pulling out of an alliance doesn't necessarily mean the end of negotiations. "The Taliban or the pharmaceutical industry can be your partner or your adversary depending on the moment and what you put on the table," Magone said. "In 2004, five of our colleagues in Afghanistan were assassinated in a province where the Taliban did not have an influence ... But they claimed they killed our colleagues. A few years later we came back and tried to reestablish a dialogue, above all because they were ready. They told us they were not behind the assassinations, but they had an interest in 2004 to claim they were because they wanted to show they could spoil the peace process and extend their power to a province where in fact they had no network. In 2008 ... they wanted to be seen as a government-in-exile, and to win over the hearts and minds of the population, they agreed to have MSF offer medical relief."

"We're now mature enough to realize we shouldn't fight against people who want to bring relief," she added. "I feel the main danger is to lie to ourselves about the sense and reality of what we do. As long as we pretend that humanitarian action is just about respecting principles, we won't be talking about what is at stake or [or taking advantage of opportunities to make the] changes we want to obtain from these powers." - Lauren Vogel, CMAJ

CMAJ 2012. DOI:10.1503/cmaj.109-4131 